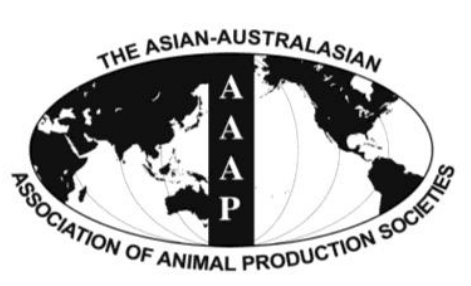

Open Access

Asian Australas. J. Anim. Sci.

Vol. 28, No. 2 : 207-214 February 2015

http://dx.doi.org/10.5713/ajas.13.0705

www.ajas.info

pISSN 1011-2367 elSSN 1976-5517

\title{
Effect of High Dietary Carbohydrate on the Growth Performance, Blood Chemistry, Hepatic Enzyme Activities and Growth Hormone Gene Expression of Wuchang Bream (Megalobrama amblycephala) at Two Temperatures
}

\author{
Chuanpeng Zhou ${ }^{1,2}$, Xianping Ge ${ }^{1, *}$, Bo Liu ${ }^{1}$, Jun Xie ${ }^{1}$, Ruli Chen ${ }^{1}$, and Mingchun Ren ${ }^{1}$ \\ ${ }^{1}$ Key Laboratory of Freshwater Fisheries and Germplasm Resources Utilization, Ministry of Agriculture, \\ Freshwater Fisheries Research Center, Chinese Academy of Fishery Sciences, Wuxi, Jiangsu 214081, China
}

\begin{abstract}
The effects of high carbohydrate diet on growth, serum physiological response, and hepatic heat shock protein 70 expression in Wuchang bream were determined at $25^{\circ} \mathrm{C}$ and $30^{\circ} \mathrm{C}$. At each temperature, the fish fed the control diet (31\% $\left.\mathrm{CHO}\right)$ had significantly higher weight gain, specific growth rate, protein efficiency ratio and hepatic glucose-6-phosphatase activities, lower feed conversion ratio and hepatosomatic index (HSI), whole crude lipid, serum glucose, hepatic glucokinase (GK) activity than those fed the high-carbohydrate diet $(47 \% \mathrm{CHO})(\mathrm{p}<0.05)$. The fish reared at $25^{\circ} \mathrm{C}$ had significantly higher whole body crude protein and ash, serum cholesterol and triglyceride, hepatic G-6-Pase activity, lower glycogen content and relative levels of hepatic growth hormone $(G H)$ gene expression than those reared at $30^{\circ} \mathrm{C}(\mathrm{p}<0.05)$. Significant interaction between temperature and diet was found for HSI, condition factor, hepatic GK activity and the relative levels of hepatic GH gene expression ( $<<0.05)$. (Key Words: Megalobrama amblycephala, Dietary Carbohydrate, Temperature, Growth, Serum Parameters, Hepatic Enzymes Activities)
\end{abstract}

\section{INTRODUCTION}

The carbohydrate utilization of fish varies between fish species and carbohydrate sources (Wilson, 1994; Krogdahl et al., 2005). Fish are known to have a limited ability for digestion and metabolism of carbohydrate and hence, excessive intake of this nutrient may result in nutritional problems (Jauncey, 1982; Roberts, 1989; Lall, 1991). Excess carbohydrates reduce the growth rate and are often accompanied by poor feed utilization (Hemre et al., 2002). Fish species are poikilothermic and their feed intake, growth and metabolic responses are affected by surrounding temperature (Peres and Oliva-Teles, 1999). Temperature is one of the key factors influencing the physiological

\footnotetext{
* Corresponding Author: X. P. Ge. Tel: +86-510-85557892, Fax: +86-510-85553304, E-mail: gexp@ffrc.cn

${ }^{2}$ South China Sea Fisheries Research Institute, Chinese Academy of Fishery Science, Guangzhou, China.

Submitted Nov. 8, 2013; Revised Jan. 27, 2014; Accepted Jul. 20, 2014
}

characteristics of ectotherms (Jobling, 1994; Gillooly et al., 2001; Hochachka and Somero, 2002; Clarke, 2004), and it also modulates utilization of nutrients by fish (Keembiyehetty and Wilson, 1998). Brett et al. (1969) reported that fish convert their food to energy more efficiently near their optimal temperature. Increasing water temperature improved starch digestibility (Médale et al., 1999) while enzyme activities were higher at lower temperatures, denoting thermal compensation for acclimation to low temperature in carp (Shikata et al., 1995). Besides growth performance, temperature was shown to affect feed efficiency, protein utilization, body composition and glycolytic, lipogenic, and gluconeogenic capacities in European sea bass (Person-Le Ruyet et al., 2004; Enes et al., 2006; Moreira et al., 2008).

Wuchang bream (Megalobrama amblycephala) is a Chinese freshwater herbivorous species (Ke, 1975) with high potential for aquaculture. Its optimum temperature is about $25^{\circ} \mathrm{C}(\mathrm{Ke}, 1986)$. Due to the merits of this species 
including tender flesh, fast growth, economic profitability and cultural values (Zhou et al., 2008), Wuchang bream is widely cultured in China with the output of 625,789 tons in 2009 - an increase of $31.5 \%$ in the past decade. This species has been introduced to North America (northern Canada to southern Mexico), Africa, Europe, and other Asian countries (Ke, 1986).

Recent studies showed that capacity for carbohydrate utilization of Wuchang bream was reported to be between 25\% and 34\% (Yang et al., 1989; Zhou et al., 2013). However, the effect of high dietary CHO level on the growth and physiological responses of Wuchang bream reared at different temperatures are not known. Thus, the objectives of this study are to examine whether the effects of high dietary $\mathrm{CHO}$ on the growth performance, blood chemistry, hepatic enzyme activities and the expression of hepatic growth hormone $(\mathrm{GH})$ in Wuchang bream at different water temperatures and to try to identify the molecular mechanisms for these effects.

\section{MATERIALS AND METHODS}

\section{Fish and diets}

Juvenile Wuchang bream, M. amblycephala $(15.73 \pm 0.03 \mathrm{~g})$, were obtained by fish farm of Freshwater Fisheries Research Center, Chinese Academy of Fishery Sciences in China. Fish were acclimated at either $25 \pm 0.5^{\circ} \mathrm{C}$ or $30 \pm 0.5^{\circ} \mathrm{C}$ in cylindrical fibreglass tanks $(300 \mathrm{~L})$ in a recirculating system for 15 days before the feeding experiment. During the period, fish were fed to apparent satiation with a control diet every day. The water oxygen content was approximately $6.0 \mathrm{mg} / \mathrm{L}$ during the experimental period. A $12 \mathrm{~L}: 12$ D photoperiod was used.

Using fishmeal as protein source, fish oil as lipid source and cassava starch as carbohydrate source, two isonitrogenous ( $34 \%$ crude protein) and isolipidic $(8.1 \%$ crude lipid) semi-purified diets were formulated to contain $31 \%$ and $47 \%$ carbohydrate, and these were referred to as a control and a high carbohydrate level respectively (Table 1). Dry ingredients were mixed thoroughly in a mixer, then water was added and mixed. Two-mm-diameter pellets were wet-extruded. The pellets were dried in a forced air oven at $40{ }^{\circ} \mathrm{C}$ to a moisture content of $10 \%$ and then stored at $-20^{\circ} \mathrm{C}$ until use.

\section{Rearing management}

At the start of the experiment, the fish were fasted for $24 \mathrm{~h}$ and then weighed. Nine fish from each temperature were sampled. The fish from each temperature were then divided into two groups, each group comprising three tanks of 20 fish, and fish fed to satiation with the control and high-carbohydrate diets three times (06:30, 11:30, and 16:30 hours respectively) daily for 8 weeks. Water was
Table 1. Formulation and nutrient compositions of experimental diets

\begin{tabular}{lcc}
\hline & \multicolumn{2}{c}{ Dietary carbohydrate levels (\%) } \\
\cline { 2 - 3 } Items & Control diet & $\begin{array}{c}\text { High-carbohydrate } \\
\text { diet }\end{array}$ \\
\hline Ingredients (\%) $^{\text {Fish meal }}{ }^{1}$ & 47 & 47 \\
Cassava starch $^{2}$ & 30 & 45 \\
Microcrystalline cellulose $^{3}$ & 15 & 0 \\
Carboxyl-methyl cellulose $^{4}$ & 2 & 2 \\
Fish oil $^{5}$ & 4 & 4 \\
Vitamin mixture $^{6}$ & 0.5 & 0.5 \\
Mineral mixture $^{7}$ & 1 & 1 \\
Zeolite power $^{8}$ & 0.5 & 0.5 \\
Proximate composition (\% dry matter) & \\
Dry matter $^{\text {Crude protein }}$ & 94.79 & 94.79 \\
Gross energy (kJ/g) $^{9}$ & 33.66 & 33.71 \\
Crude lipid $_{\text {Digestible carbohydrate }}$ & 16.56 & 19.25 \\
\hline
\end{tabular}

$\mathrm{CP}$, crude protein; EE, ether extract.

${ }^{1}$ Fish meal (CP $67.70 \%$, EE $7.90 \%$, carbohydrate $0.45 \%$, ash $16.70 \%$, Norway fish meal, Shanghai Imports and Exports Co. Ltd., China).

${ }^{2}$ Cassava starch (Wuxi Yongfeng starch Engineering Co., Ltd., China).

${ }^{3}$ Microcrystalline cellulose (Zhejiang Joinway Pharmaceutical Co., Ltd.).

${ }^{4}$ Carboxyl-methyl cellulose (Shanghai Jiande Industrial Co., Ltd.).

${ }^{5}$ Fish oil (Wuxi Xunda Ocean Biological Co. Ltd., China).

${ }^{6}$ Vitamin (IU or per $\mathrm{kg}$ premix): vitamin A, 900,000 IU; vitamin D, 250,000 IU; vitamin E, 4,500 mg; vitamin $K_{3}, 220 \mathrm{mg}$; vitamin $B_{1}, 320$ $\mathrm{mg}$; vitamin $\mathrm{B}_{2}, 1,090 \mathrm{mg}$; vitamin $\mathrm{B}_{5}, 2,000 \mathrm{mg}$; vitamin $\mathrm{B}_{6}, 500 \mathrm{mg}$; vitamin $\mathrm{B}_{12}, 116 \mathrm{mg}$; vitamin $\mathrm{C}, 5,000 \mathrm{mg}$; pantothenate, $1,000 \mathrm{mg}$; folic acid, $165 \mathrm{mg}$; choline, $60,000 \mathrm{mg}$.

${ }^{7}$ Mineral (per kg premix): $\mathrm{CuSO}_{4} \cdot 5 \mathrm{H}_{2} \mathrm{O}, 2.5 \mathrm{~g} ; \mathrm{FeSO}_{4} \cdot 7 \mathrm{H}_{2} \mathrm{O}, 28 \mathrm{~g}$; $\mathrm{ZnSO}_{4} \cdot 7 \mathrm{H}_{2} \mathrm{O}, 22 \mathrm{~g} ; \mathrm{MnSO}_{4} \cdot 4 \mathrm{H}_{2} \mathrm{O}, 9 \mathrm{~g} ; \mathrm{Na}_{2} \mathrm{SeO}_{3}, 0.045 \mathrm{~g} ; \mathrm{KI}, 0.026 \mathrm{~g}$; $\mathrm{CoCl}_{2} \cdot 6 \mathrm{H}_{2} \mathrm{O}, 0.1 \mathrm{~g}$

${ }^{8}$ Zeolite powder (Nanjing Huamu Animal Research Institute, China).

${ }^{9}$ Gross energy (GE) kJ/g: protein, $23.64 \mathrm{~kJ} / \mathrm{g}$; fat, $39.54 \mathrm{~kJ} / \mathrm{g}$; carbohydrate, $17.15 \mathrm{~kJ} / \mathrm{g}$; and the others are measured in the nutrition levels.

oxygenated at all times using an aerator. Feces and debris were removed daily using a siphon. Water temperature was measured every day, and water quality was measured every week. During this period, feed consumption was recorded daily. The number and weight of the dead fish was also recorded. During the test period, the water quality on average was as follows: dissolved oxygen (DO) $>6 \mathrm{mg} / \mathrm{L}$, $\mathrm{NH}_{3}<0.05 \mathrm{mg} / \mathrm{L}, \mathrm{H}_{2} \mathrm{~S}<0.1 \mathrm{mg} / \mathrm{L}$, and $\mathrm{pH} 6.8$ to 7.3. After the completion of the test period (70 days), serum and liver samples were collected. At the end of the feeding trial, the fish were fasted for $24 \mathrm{~h}$, and then counted and weighed. The serum and liver samples were collected.

\section{Serum and liver sample collection}

At the end of the growth trial, the fish were starved for $24 \mathrm{~h}$ and weighed. Nine individuals from each group (3 tanks, 3 fish per tank) were anesthetized with MS-222 and 
sampled. Blood was sampled from the caudal vein, centrifuged at 3,000 $\mathrm{g}$ for $10 \mathrm{~min}\left(4^{\circ} \mathrm{C}\right)$, and kept frozen until analysis. The liver was excised, frozen in liquid nitrogen and then stored at $-80^{\circ} \mathrm{C}$ until assay.

\section{Proximate analysis}

The contents of dry matter, crude protein, crude lipid, and ash were determined for the experimental diets and the fish bodies. Chemical analyses were conducted using the following AOAC (1997) procedure: dry matter by drying in an oven at $105^{\circ} \mathrm{C}$ to a constant weight; crude protein (nitrogen $\times 6.25$ ) using the Kjeldahl method after acid digestion (FOSS KT260, Höganäs, Sweden); crude lipid by ether-extraction in a Soxtec System HT (Soxtec System HT6, Tecator, Höganäs, Sweden); and ash by incineration in a muffle furnace at $550^{\circ} \mathrm{C}$ for $4 \mathrm{~h}$. Carbohydrate contents of feed were analyzed by the 3,5-dinitro salicylic acid method (Yu et al., 1997). The hepatic glycogen content was determined as described in Plummer (1987).

\section{Plasma glucose, triglyceride, and cholesterol levels}

Plasma glucose, triglyceride, and cholesterol content were measured using the glucose oxidase method, the enzymatic (glycerol phosphate oxidase) and colorimetric (PAP) method, and the enzymatic (cholesterol oxidase) and colorimetric method, respectively, using test kits purchased from Junshi Biotechnology Co., Ltd. (Shanghai, China).

\section{Enzyme activity analysis}

A frozen sample of liver was homogenized (dilution 1/10) in ice-cold buffer consisting of $80 \mathrm{mM}$ Tris ( $\mathrm{pH} 7.5)$, $5 \mathrm{mM}$ ethylene diamine tetraacetic acid (EDTA), $1 \mathrm{mM}$ $\mathrm{KH}_{2} \mathrm{PO}_{4}, 2 \mathrm{mM} \mathrm{NaHCO}$ and $1.4 \mathrm{mM}$ dithiothreitol. The homogenate was centrifuged at 4,000 rpm for $10 \mathrm{~min}$ at $4{ }^{\circ} \mathrm{C}$ (Cai, 2004), and then the supernatant was centrifuged at $12,000 \mathrm{rpm}$ for $20 \mathrm{~min}$ at $4^{\circ} \mathrm{C}$. The supernatant was separated and divided into three parts for measurement of glucokinase (GK), phosphoenolpyruvate carboxykinase (PEPCK), and glucose-6-phosphatase (G6Pase) activity.

Glucokinase (EC2.7.1.2) activity was measured using the glucose-6-phosphate dehydrogenase (G6PDH) coupling method (Tranulis et al., 1996; Panserat et al., 2000a). The reaction system contained $65 \mathrm{mU} / \mathrm{mL}$ G6PDH, $2 \mathrm{mM}$ $\mathrm{NADP}^{+}$(oxidized form of nicotinamide-adenine dinucleotide phosphate) $7 \mathrm{mM}$ adenosine triphosphate, 80

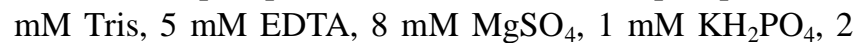
$\mathrm{mM} \mathrm{NaHCO}, 0.2 \mathrm{mM}$ dithiothreitol, and $100 \mathrm{mM}$ glucose at $\mathrm{pH}$ 8.2. The glucose concentration was $0.64 \mathrm{mM}$ to 1,277 $\mathrm{mM}$ in the kinetic study. This assay for measuring GK activity using frozen samples necessitated correction by measuring glucose dehydrogenase activity (E.C. 1.1.1.47) as described previously (Tranulis et al., 1996). One unit of GK activity was defined as the amount of NADPH (reduced form of nicotinamide-adenine dinucleotide phosphate) generated by per $\mathrm{g}$ protein per minute at $30^{\circ} \mathrm{C}$.

Phosphoenolpyruvate carboxykinase (EC4.1.1.32) activity was measured according to the methods described by Kirchner et al. (2003). The reaction system contained 2 $\mathrm{mM}$ nosine-5'-diphosphate disodium salt, $5 \mathrm{mM} \mathrm{MnCl}_{2}, 1.1$ $\mathrm{U} / \mathrm{mL}$ malate dehydrogenase, $2.5 \mathrm{mM}$ phosphoenolpyruvic acid monopotassium salt, $0.12 \mathrm{mM} \mathrm{NADH}$ (reduced form of nicotinamide-adenine dinucleotid) and $0.1 \mathrm{~mol} / \mathrm{L}$ Tris$\mathrm{HCl}$ ( $\mathrm{pH} \mathrm{7.4).} \mathrm{One} \mathrm{unit} \mathrm{of} \mathrm{PEPCK} \mathrm{activity} \mathrm{was} \mathrm{defined} \mathrm{as}$ the amount of $\mathrm{NADH}$ generated by per $\mathrm{g}$ protein per minute at $30^{\circ} \mathrm{C}$.

The G6Pase (EC3. 1. 3. 9) activity was measured following the methods described by Panserat et al. (2000b). The reaction system contained $26.5 \mathrm{mM}$ G6P, $1.8 \mathrm{mM}$ EDTA, $2 \mathrm{mM} \mathrm{NAD}{ }^{+}, 0.5$ to $\mathrm{U} / \mathrm{mL}$ mutarotase, 5 to $7 \mathrm{U} / \mathrm{mL}$ glucose dehydrogenase, and $100 \mathrm{mM}$ imidazole-HCl. One unit of G6Pase activity was defined as the amount of enzyme that catalyzed the hydrolysis of $1 \mu \mathrm{M}$ of glucose-6phosphate/min under the specified conditions $\left(30^{\circ} \mathrm{C}\right)$.

All enzyme activities were expressed per $\mathrm{mg}$ of total protein (specific activity). The total protein content in crude extracts was determined at $30^{\circ} \mathrm{C}$ using bovine serum albumin as a standard based on the method of Bradford (1976).

\section{Real-time polymerase chain reaction measurement of hepatic growth hormone gene}

We used the $M$. amblycephala cDNA sequences in GenBank to design the primers for GH (accession No AF463498.2) and $\beta$-actin (accession No AY170122.2) (Zhou et al., 2013). The primers were 5'-GCGGAG CCATCTCAAACAGCC-3' and 5'-AAGCAAGCCAGAA GACGAAAG-3' for GH and 5'-TCGTCCACCGCAAA TGCTTCTA-3' and 5'-CCGTCACCTTCACCGTTCCA GT-3' for $\beta$-actin. All primer pairs were synthesized by Shanghai Generay Biotech Co., Ltd. (Shanghai, China). They amplified a single polymerase chain reaction (PCR) product with the expected size as determined by the Tm value, agarose gel electrophoresis, and melting curve analysis. The PCR products were 100 to $150 \mathrm{bp}$ long.

We extracted RNA from the liver tissue using RNAiso Plus (Dalian Takara Co. Ltd., China). RNA samples were treated with RQ1 RNase-Free DNase (Takara Co. Ltd., Dalian, China) to avoid genomic DNA amplification. We generated cDNA from $500 \mathrm{ng}$ DNase-treated RNA using ExScript RT-PCR Kit (Takara Co. Ltd., Dalian, China). The reverse transcription PCR reaction solution consisted of 500 ng RNA, $2 \mu \mathrm{L} 5 \times$ Buffer, $0.5 \mu \mathrm{L}$ dNTP Mixture $(10 \mathrm{mM}$ each), $0.25 \mu \mathrm{L}$ RNase Inhibitor $(40 \mathrm{U} / \mu \mathrm{L}), 0.5 \mu \mathrm{L}$ OligodTadaptor primer $(50 \mathrm{mM}), 0.25 \mathrm{~mL}$ ExScript RTase (200 $\mathrm{U} / \mu \mathrm{L}$ ), and diethylpyrocarbonate $\mathrm{H}_{2} \mathrm{O}$, up to a final volume of $10 \mu \mathrm{L}$. The reaction conditions were as follows: $37^{\circ} \mathrm{C}$ for 
$15 \mathrm{~min}, 85^{\circ} \mathrm{C}$ for $5 \mathrm{~s}$, and $4^{\circ} \mathrm{C}$ thereafter.

We used real-time PCR to determine mRNA levels using an SYBR Green I fluorescence kit (Zhou et al., 2013). Real-time PCR was performed in a Mini Opticon RealTime Detector (Bio-Rad, Hercules, CA, USA). The fluorescent quantitative PCR reaction solution consisted of 12.5 $\mu \mathrm{L}$ SYBR premix Ex Taq $(2 \times), 0.5 \mu \mathrm{L}$ PCR Forward Primer $(10 \mu \mathrm{M}), 0.5 \mu \mathrm{L}$ PCR Reverse Primer $(10 \mu \mathrm{M}), 2.0$ $\mu \mathrm{L}$ reverse transcript reaction mix (cDNA solution), and 9.5 $\mu \mathrm{L} \mathrm{dH_{2 }} \mathrm{O}$. The reaction conditions were as follows: $95^{\circ} \mathrm{C}$ for $2 \mathrm{~min}$, followed by 44 cycles consisting of $95^{\circ} \mathrm{C}$ for $10 \mathrm{~s}$, $62^{\circ} \mathrm{C}$ for $20 \mathrm{~s}$, and $72^{\circ} \mathrm{C}$ for $15 \mathrm{~s}$. The fluorescent flux was then recorded and the reaction continued at $72^{\circ} \mathrm{C}$ for $3 \mathrm{~min}$. We measured the dissolution rate between $65^{\circ} \mathrm{C}$ and $92^{\circ} \mathrm{C}$. Each increase of $0.2^{\circ} \mathrm{C}$ was maintained for $1 \mathrm{~s}$ and the fluorescent flux was recorded. We calculated the relative quantification of the target gene transcript $(\mathrm{GH})$ with a chosen reference gene transcript $\left(\beta\right.$-actin) using the $2^{-\Delta \Delta \mathrm{CT}}$ method. This mathematical algorithm, which does not require a calibration curve, computes an expression ratio based on real-time PCR efficiency and the crossing point deviation of the sample versus a control. We measured the PCR efficiency by constructing a standard curve using a serial dilution of cDNA; $\Delta \Delta \mathrm{C}_{\mathrm{T}}=\left(\mathrm{C}_{\mathrm{T}}\right.$, Target $\left.-\mathrm{C}_{\mathrm{T}, \beta \text {-actin }}\right)$ time $\mathrm{x}$ $-\left(\mathrm{C}_{\mathrm{T} \text {, Target }}-\mathrm{C}_{\mathrm{T}, \beta \text {-actin }}\right)$ time 0 .

\section{Calculations and statistics}

Weight gain (WG, \%)

$=($ final body weight - initial body weight $)$ $\times 100$ /initial body weight

Specific growth rate $(\mathrm{SGR}, \%)=\left(\mathrm{LnW}_{\mathrm{t}}-\mathrm{LnW}_{0}\right) \times 100 / T$

where $\mathrm{W}_{0}$ and $\mathrm{W}_{\mathrm{t}}$ are the initial and final body weights, and $T$ is the culture period in days.
Feed conversion ratio (FCR, \%)

$=$ total diet fed $(\mathrm{kg}) /$ total wet weight gain $(\mathrm{kg})$

Feeding rate (FR)

$=100 \times$ dry feed intake

$/[($ initial wet body mass+final wet body mass $) / 2 \times \mathrm{T}]$

Hepatosomatic index (HSI)

$=($ liver weight $\times 100) /$ body weight

Viserosomatic index (VSI)

$=100 \times$ terminal gut weight/terminal wet body weight

Condition factor $(\mathrm{CF})$

$=($ body weight $\times 100) /$ total body length $(\mathrm{cm})^{3}$

Protein efficiency ratio (PER)

= final wet weight gain/protein intake

Results are presented as mean \pm standard error. Data were analyzed by two-way analysis of variance using the SPSS 16.0 (SPSS, IL, USA). A p-value of <0.05 indicated that there was a significant difference.

\section{RESULTS}

\section{Growth performance and feed utilization}

Growth performance and feed utilization of $M$. amblycephala are presented in Table 2. After the 8-week feeding trial, survival rates of fish were all above $89 \%$ and showed little difference ( $p>0.05)$ among all the treatments. At each temperature, final body weight, WG, SGR, and PER of fish fed the control diet were significantly higher than those fed the high-carbohydrate diet, and the FCR and HSI of the fish fed the control diet was lower than that fed

Table 2. Effect of high dietary carbohydrate diet on growth performance and feed utilization of Wuchang bream (M. amblycephala) at different temperatures

\begin{tabular}{|c|c|c|c|c|c|c|c|}
\hline \multirow{2}{*}{ Variables } & \multicolumn{2}{|c|}{$31 \%$ dietary carbohydrate } & \multicolumn{2}{|c|}{$47 \%$ dietary carbohydrate } & \multicolumn{3}{|c|}{ Two-way ANOVA } \\
\hline & $25^{\circ} \mathrm{C}$ & $30^{\circ} \mathrm{C}$ & $25^{\circ} \mathrm{C}$ & $30^{\circ} \mathrm{C}$ & Carbohydrate & Temperature & Interaction \\
\hline $\begin{array}{l}\text { Survival (\%) } \\
\text { ( }\end{array}$ & $94.00 \pm 2.31$ & $92.67 \pm 3.18$ & $93.00 \pm 2.52$ & $89.00 \pm 1.73$ & 0.085 & 0.078 & 0.096 \\
\hline Initial body weight (g) & $15.80 \pm 0.06$ & $15.67 \pm 0.03$ & $15.77 \pm 0.07$ & $15.67 \pm 0.09$ & 0.803 & 0.108 & 0.803 \\
\hline Final body weight (g) & $53.40 \pm 0.04^{\mathrm{a}}$ & $49.51 \pm 0.62^{\mathrm{b}}$ & $49.31 \pm 0.86^{b c}$ & $47.04 \pm 0.92^{\mathrm{c}}$ & 0.009 & 0.065 & 0.423 \\
\hline WG $(\%)$ & $237.97 \pm 7.75$ & $216.07 \pm 4.61$ & $212.76 \pm 4.83$ & $200.26 \pm 7.34$ & 0.009 & 0.058 & 0.456 \\
\hline SGR $(\%)$ & $2.17 \pm 0.03$ & $2.05 \pm 0.03$ & $2.04 \pm 0.03$ & $1.96 \pm 0.04$ & 0.011 & 0.064 & 0.516 \\
\hline FCR & $1.60 \pm 0.04$ & $2.23 \pm 0.14$ & $2.31 \pm 0.2$ & $2.93 \pm 0.31$ & 0.037 & 0.059 & 0.939 \\
\hline FR $(\%)$ & $2.71 \pm 0.11$ & $2.72 \pm 0.02$ & $2.73 \pm 0.03$ & $2.80 \pm 0.03$ & 0.420 & 0.482 & 0.586 \\
\hline HSI (\%) & $1.97 \pm 0.03$ & $1.80 \pm 0.03$ & $2.10 \pm 0.06$ & $2.20 \pm 0.04$ & 0.000 & 0.408 & 0.013 \\
\hline VSI (\%) & $11.95 \pm 0.20$ & $12.38 \pm 0.10$ & $12.39 \pm 0.34$ & $12.40 \pm 0.09$ & 0.304 & 0.318 & 0.339 \\
\hline $\mathrm{CF}$ & $2.11 \pm 0.05$ & $2.19 \pm 0.01$ & $2.21 \pm 0.05$ & $2.10 \pm 0.04$ & 0.868 & 0.620 & 0.043 \\
\hline PER & $2.62 \pm 0.11$ & $2.59 \pm 0.03$ & $2.55 \pm 0.07$ & $2.26 \pm 0.02$ & 0.017 & 0.063 & 0.079 \\
\hline
\end{tabular}

ANOVA, analysis of variance; WG, weight gain; SGR, specific growth rate; FCR, feed conversion ratio; FR, feeding rate; HSI, hepatosomatic index; VSI, viserosomatic index; $\mathrm{CF}$, condition factor; PER, protein efficiency ratio; SE, standard error.

Values are means $\pm S E(n=9), p<0.05$ indicated that there was a significant difference. 
Table 3. Effect of high dietary carbohydrate diet on body composition and hepatic glycogen of Wuchang bream (M. amblycephala) at different temperatures

\begin{tabular}{|c|c|c|c|c|c|c|c|}
\hline \multirow{2}{*}{ Variables } & \multicolumn{2}{|c|}{$31 \%$ dietary carbohydrate } & \multicolumn{2}{|c|}{$47 \%$ dietary carbohydrate } & \multicolumn{3}{|c|}{ Two-way ANOVA } \\
\hline & $25^{\circ} \mathrm{C}$ & $30^{\circ} \mathrm{C}$ & $25^{\circ} \mathrm{C}$ & $30^{\circ} \mathrm{C}$ & Carbohydrate & Temperature & Interaction \\
\hline$\overline{\text { Glycogen }(\mathrm{mg} / \mathrm{g})}$ & $17.90 \pm 0.93$ & $22.82 \pm 0.64$ & $20.71 \pm 0.80$ & $25.77 \pm 0.94$ & 0.063 & 0.039 & 0.932 \\
\hline Moisture (\%) & $74.96 \pm 1.64$ & $76.61 \pm 0.57$ & $74.94 \pm 0.64$ & $76.51 \pm 1.38$ & 0.200 & 0.958 & 0.973 \\
\hline Crude protein $(\%)$ & $15.14 \pm 0.68$ & $13.51 \pm 0.47$ & $15.95 \pm 0.59$ & $12.56 \pm 0.84$ & 0.916 & 0.005 & 0.219 \\
\hline Crude lipid (\%) & $5.45 \pm 0.51$ & $5.79 \pm 0.14$ & $6.58 \pm 0.39$ & $6.98 \pm 0.50$ & 0.022 & 0.396 & 0.934 \\
\hline Ash (\%) & $4.40 \pm 0.36$ & $4.09 \pm 0.03$ & $4.80 \pm 0.27$ & $3.95 \pm 0.17$ & 0.604 & 0.042 & 0.295 \\
\hline
\end{tabular}

ANOVA, analysis of variance; SE, standard error.

Values are means $\pm \operatorname{SE}(n=9), \mathrm{p}<0.05$ indicated that there was a significant difference.

the high-carbohydrate diet $(\mathrm{p}<0.05)$. The FR, HSI, VSI, CF and PER were not significantly different between two temperatures $(p>0.05)$. The FR, VSI, and CF were not significantly different between diets at each temperature $(p>0.05)$. Significant interaction between temperature and diet was found for HSI and CF $(\mathrm{p}<0.05)$.

\section{Body composition}

Proximate composition of whole body of $M$. amblycephala are shown in Table 3. Compared to those reared at $30^{\circ} \mathrm{C}$, the fish reared at $25^{\circ} \mathrm{C}$ had lower glycogen content, higher crude protein and ash in whole body $(p<0.05)$. At each temperature, crude lipid in whole body of the fish fed the control diet was lower than that fed the high-carbohydrate diet $(p<0.05)$. The glycogen content, moisture, crude protein and ash in whole body were not significantly different between diets at each temperature $(p>0.05)$. The crude lipid and moisture in whole body were not affected by temperature $(\mathrm{p}>0.05)$.

\section{Serum glucose, cholesterol, and triglyceride levels}

Serum glucose, cholesterol, and triglyceride levels of $M$. amblycephala are shown in Table 4. Compared to those reared at $25^{\circ} \mathrm{C}$, the fish reared at $30^{\circ} \mathrm{C}$ had lower serum cholesterol and triglyceride $(\mathrm{p}<0.05)$. At each temperature, serum glucose of the fish fed the control diet was lower than that fed the high-carbohydrate diet $(\mathrm{p}<0.05)$. The serum cholesterol and triglyceride were not significantly different between diets at each temperature $(p>0.05)$. The serum glucose was not affected by temperature $(p>0.05)$ (Table 4).

\section{Hepatic enzyme activities}

Hepatic enzyme activities of $M$. amblycephala are shown in Table 5. Compared to those reared at $30^{\circ} \mathrm{C}$, the fish reared at $25^{\circ} \mathrm{C}$ had higher hepatic G-6-Pase activity $(\mathrm{p}<0.05)$. At each temperature, the fish fed the control diet had lower hepatic GK activity, higher hepatic G-6-Pase activities $(\mathrm{p}<0.05)$. The hepatic PEPCK activity was not significantly different between diets at each temperature

Table 4. Effect of high dietary carbohydrate diet on serum glucose, cholesterol and triglyceride levels of Wuchang bream $(M$. amblycephala) at different temperatures

\begin{tabular}{|c|c|c|c|c|c|c|c|}
\hline \multirow{2}{*}{ Variables } & \multicolumn{2}{|c|}{$31 \%$ dietary carbohydrate } & \multicolumn{2}{|c|}{$47 \%$ dietary carbohydrate } & \multicolumn{3}{|c|}{ Two-way ANOVA } \\
\hline & $25^{\circ} \mathrm{C}$ & $30^{\circ} \mathrm{C}$ & $25^{\circ} \mathrm{C}$ & $30^{\circ} \mathrm{C}$ & Carbohydrate & Temperature & Interaction \\
\hline$\overline{\text { Glucose }(\mathrm{mmol} / \mathrm{L})}$ & $6.17 \pm 0.36$ & $6.46 \pm 0.11$ & $6.60 \pm 0.06$ & $7.65 \pm 0.18$ & 0.005 & 0.112 & 0.340 \\
\hline Cholesterol (mmol/L) & $4.41 \pm 0.23$ & $3.67 \pm 0.14$ & $4.47 \pm 0.24$ & $4.13 \pm 0.12$ & 0.204 & 0.022 & 0.332 \\
\hline Triglyceride (mmol/L) & $4.45 \pm 0.26$ & $3.43 \pm 0.05$ & $4.11 \pm 0.08$ & $3.23 \pm 0.07$ & 0.090 & 0.000 & 0.647 \\
\hline
\end{tabular}

ANOVA, analysis of variance; SE, standard error.

Values are means $\pm \operatorname{SE}(n=9), p<0.05$ indicated that there was a significant difference.

Table 5. Effect of high dietary carbohydrate diet on carbohydrate metabolic enzymes activities and hepatic growth hormone gene expression of Wuchang bream (M. amblycephala) at different temperatures

\begin{tabular}{|c|c|c|c|c|c|c|c|}
\hline \multirow{2}{*}{ Variables } & \multicolumn{2}{|c|}{$31 \%$ dietary carbohydrate } & \multicolumn{2}{|c|}{$47 \%$ dietary carbohydrate } & \multicolumn{3}{|c|}{ Two-way ANOVA } \\
\hline & $25^{\circ} \mathrm{C}$ & $30^{\circ} \mathrm{C}$ & $25^{\circ} \mathrm{C}$ & $30^{\circ} \mathrm{C}$ & Carbohydrate & Temperature & Interaction \\
\hline$\overline{\mathrm{GK}}(\mathrm{mU} / \mathrm{mg})$ & $8.79 \pm 0.88$ & $13.80 \pm 0.67$ & $14.08 \pm 0.68$ & $15.37 \pm 0.85$ & 0.002 & 0.063 & 0.043 \\
\hline PEPCK (mU/mg) & $12.66 \pm 0.31$ & $12.39 \pm 1.12$ & $11.92 \pm 0.83$ & $14.23 \pm 0.19$ & 0.468 & 0.197 & 0.112 \\
\hline G6Pase (mU/mg) & $18.68 \pm 0.47$ & $13.52 \pm 0.66$ & $14.62 \pm 0.60$ & $10.86 \pm 0.19$ & 0.011 & 0.014 & 0.209 \\
\hline $\begin{array}{l}\text { Hepatic growth hormone } \\
\text { of mRNA }\end{array}$ & $1.06 \pm 0.03$ & $2.46 \pm 0.05$ & $1.74 \pm 0.03$ & $1.96 \pm 0.06$ & 0.070 & 0.024 & 0.006 \\
\hline
\end{tabular}

ANOVA, analysis of variance; GK, glucokinase; PEPCK, phosphoenolpyruvate carboxykinase; G6Pase, glucose-6-phosphatase; SE, standard error. Values are means $\pm \operatorname{SE}(n=9), p<0.05$ indicated that there was a significant difference. 
( $p>0.05)$. The hepatic GK and PEPCK activities were not affected by temperature $(p>0.05)$. Significant interaction between temperature and diet was found for hepatic GK activity $(\mathrm{p}<0.05)$.

\section{Hepatic growth hormone gene expression}

Hepatic $G H$ gene expression of $M$. amblycephala are also shown in Table 5. Compared to that reared at $25^{\circ} \mathrm{C}$, the fish reared at $30^{\circ} \mathrm{C}$ had higher relative levels of hepatic $G H$ gene expression $(\mathrm{p}<0.05)$. The relative levels of hepatic $G H$ gene expression were not significantly different between diets at each temperature $(p>0.05)$. Significant interaction between temperature and diet was found for the relative levels of hepatic $G H$ gene expression (p<0.05) (Table 5).

\section{DISCUSSION}

Several previous studies have showed that incorporation of appropriate levels of dietary carbohydrates in fish feeds can improve their growth performance and provide an inexpensive non-nitrogenous energy source (Hemre and Hansen, 1998; Peragón et al., 1999; Vielma et al., 2003). However, excess levels of carbohydrates reduce the growth rate and feed utilization (Vielma et al., 2003; Enes et al., 2006). In this study, we found depressed growth and feed utilization in $M$. amblycephala fed diets high in carbohydrate content. The finding of our study indicated that high dietary carbohydrate may reduce the growth rate and feed utilization in M. amblycephala, similar to previous studies (Furuichi and Yone, 1980; Tan et al., 2009; Miao et al., 2011).

In general, the increase of HSI that accompanied the increasing dietary carbohydrate level may be related to the increased glycogen deposition in the liver of fish fed highcarbohydrate diets (Wilson, 1994; Moreira et al., 2008). In this study, contrary to the CF, HSI were increased when the two factors; high-carbohydrate diet and higher temperature treatment co-existed. HSI and whole body lipid content was significantly affected by the dietary carbohydrate level in the current study, as in European sea bass (Moreira et al., 2008). In our study, we found that glycogen content, crude protein and ash in whole body were affected by temperature suggesting that temperature influences the physiological characteristics of ectotherms (Gillooly et al., 2001; Hochachka and Somero, 2002; Clarke, 2004) and it also modulates utilization of nutrients by fish (Keembiyehetty and Wilson, 1998).

Serum biochemical parameters played an important role in evaluating the health of many organisms (Abdel-Tawwab et al., 2010). It is generally accepted that fish have limited ability to metabolize glucose, and high digestible carbohydrate intake results in postprandial hyperglycemia for many hours (Wilson, 1994). In our study, we found that M. amblycephala fed high-carbohydrate diet had higher serum glucose levels. A similar positive correlation between blood glucose concentration and dietary carbohydrate level was found in cobia, Rachycentron canadum L. (Ren et al., 2011). In this study, we found that M. amblycephala reared at $30^{\circ} \mathrm{C}$ had lower serum cholesterol and triglyceride, similar to a previous study on crucian carp (Carassius auratus) (Han et al., 2010).

The change of carbohydrate content in the fish diet induces pronounced changes in carbohydrate metabolism, especially in the activity of key enzymes of carbohydrate metabolism in the liver (Leung and Woo, 2012). Previous studies reported that GK activity increased with the increase in dietary carbohydrate in rainbow trout (Oncorhynchus mykiss) and gilthead sea bream (Sparus aurata) (Panserat et al., 2000b; Metón et al., 2004). The G6Pase activity decreased with the increased dietary carbohydrate level in common carp (Cyprinus carpio) and gilthead seabream (Sparus aurata) (Panserat et al., 2002). In our study, hepatic GK activity of $M$. amblycephala was increased greatly by the application of both a high-carbohydrate diet and a higher temperature. In addition, we found that temperature negatively modulated hepatic G-6-Pase activity. Thus, both dietary composition and temperature seemed to be the important factors controlling hepatic key metabolic enzymes involved in carbohydrate metabolism in Wuchang bream.

Growth hormone is synthesized in the pituitary gland and secreted into the bloodstream under the regulation of neuronal, hormonal, and nutritional factors (Duan, 1998). In fish, GH can participate in protein, fat, and carbohydrate metabolism (Donaldson et al., 1979). Growth hormone mRNA was detected in the pituitary gland, brain, gill, heart, kidney, muscle, and liver of common carp (Kumar et al., 2013) and rainbow trout and coho salmon (Tymchuk et al., 2009). The content of $\mathrm{CH}$ is influenced by environmental factors such as temperature and light regime (Hemre et al., 2002). In this study, the relative level of hepatic $G H$ gene expression was increased greatly in fish subjected to the high-carbohydrate diet and higher temperature treatment. Our results were also in agreement with a previous study showing that there was an overall negative correlation between expression of the $G H$ gene and growth performance for all common carp diet groups (Kumar et al., 2013). This finding indicated that high temperature may lead to metabolic stress in M. amblycephala. This could be explained that the $\mathrm{GH}$ levels are elevated in the metabolic disorders that shared an increased catabolism/anabolism balance (Pérez-Sánchez and Le Bail, 1999). However, the relationship between temperature for M. amblycephala and $\mathrm{GH}$ remains to be further investigated. 


\section{CONCLUSION}

In conclusion, the present study suggested that HSI, CF, hepatic GK activity and the relative levels of hepatic $G H$ gene expression of $M$. amblycephala were affected greatly by the interaction between the two factors of highcarbohydrate diet and higher temperature treatment.

\section{ACKNOWLEDGMENTS}

This work was supported by the National Natural Science Foundation of China (31472289); Open Fund of Key Laboratory of Freshwater Fisheries and Germplasm Resources Utilization of Ministry of Agriculture (KF201311); the National Non-profit Institute Research Grant of Freshwater Fisheries Research Center, Chinese Academy of Fishery Sciences (2013JBFR03); the National Technology System for Conventional Freshwater Fish Industries, the Modern Agriculture Industrial Technology System (CARS-46); the Special Fund for Agro-Scientific Research in the Public Interest (201003020); Special Scientific Research Funds for Central Non-profit Institutes, South China Sea Fisheries Research Institute, Chinese Academy of Fishery Sciences (2014YD01).

\section{REFERENCES}

Abdel-Tawwab, M., M. H. Ahmad, Y. A. E. Khattab, and A. M. E. Shalaby. 2010. Effect of dietary protein level, initial body weight, and their interaction on the growth, feed utilization and physiological alterations of Nile tilapia, Oreochromis niloticus (L.). Aquaculture 298:267-274.

AOAC International. 1997. Official Methods of Analysis. 16th edn. Association of Official Analytical Chemists International, Arlington, VA, USA.

Bradford, M. M. 1976. A rapid and sensitive method for the quantitation of microgram quantities of protein utilizing the principle of protein-dye binding. Anal. Biochem. 72:248-254.

Brett, J. R., J. E. Shelboum, and C. T. Shoop. 1969. Growth rate and body composition of fingerling sockeye salmon, Oncorhynchus nerka, in relation to temperature and ration size. J. Fish. Res. Board Can. 26: 2363-2394.

Cai, C. F. 2004. Study on the utilization of dietary carbohydrate by Mylopharyngodon piecus Richardson and Carassius auratus and their mechanism of metabolism. Ph.D. Thesis. Shanghai East China Normal University, Shanghai, China.

Clarke, A. 2004. Is there a universal temperature dependence of metabolism? Funct. Ecol. 18:252-256.

Donaldson, E. M., U. H. M. Fagerlund, D. A. Higgs, and J. R. Mcbride. 1979. Hormonal enhancement of growth. Fish Physiol. 8:455-597.

Duan, C. 1998. Nutritional and developmental regulation of insulin-like growth factors in fish. J. Nutr. 128:306S-314S.

Enes, P., S. Panserat, S. Kaushik, and A. Oliva-Teles. 2006. Rapid metabolic adaptation in European sea bass (Dicentrarchus labrax) juveniles fed different carbohydrate sources after heat shock stress. Comp. Biochem. Physiol. A Mol. Integr. Physiol. 145:73-81.

Furuichi, M. and Y. Yone. 1980. Effect of dietary dextrin levels on growth and feed efficiency, the chemical composition of liver and dorsal muscle, and the absorption of dietary protein and dextrin in fishes. Bull. Japan. Soc. Sci. Fish. 46:225-229.

Gillooly, J. F., J. H. Brown, G. B. West, V. M. Savage, and E. L. Charnov. 2001. Effects of size and temperature on metabolic rate. Science 293:2248-2251.

Han, J. C., G. Y. Liu, P. S. Mei, Y. P. Huang, D. F. Liu, and Q. W. Chen. 2010. Effects of temperature on the hematological indices and digestive enzyme activities of Crucian Carp (Carassius auratus). Journal of Hydroecology 3:87-92.

Hemre, G. I. and T. Hansen. 1998. Utilisation of different dietary starch sources and tolerance to glucose loading in Atlantic salmon (Salmo salar), during parr-smolt transformation. Aquaculture 161:145-157.

Hemre, G. I., T. P. Mommsen, and A. Krogdahl. 2002. Carbohydrates in fish nutrition: Effects on growth, glucose metabolism and hepatic enzymes. Aquac. Nutr. 8:175-194.

Hochachka, P. W. and G. N. Somero. 2002. Biochemical Adaptation: Mechanism and Processing Physiological Evolution. Oxford University Press, NewYork, NY, USA.

Jauncey, K. 1982. Carp (Cyprinus carpio L.) nutrition - A review. In: Recent Advances in Aquaculture (Eds. J. F. Muir, and R. J. Roberts). Croom Helm Ltd, London, UK. 215-263.

Jobling, M. 1994. Fish Bioenergetics, Fish and Fisheries Series. Chapman and Hall, London, UK. 13:213-230.

Ke, H. 1975. An excellent freshwater food fish, Megalobrama amblycephala, and its propagating and culturing. Acta Hydrobiol. Sin. 5:293-312.

Ke, H. 1986. Cultivation of blunt snout bream (Megalobrama amblycephala) in China. Fish. Sci. Technol. Inf. 5:1-5.

Keembiyehetty, C. N. and R. P. Wilson. 1998. Effect of water temperature on growth and nutrient utilization of sunshine bass (Morone chrysops $\times$ Morone saxatilis) fed diets containing different energy/protein ratios. Aquaculture 166:151-162.

Kirchner, S., S. Kaushik, and S. Panserat. 2003. Effect of partial substitution of dietary protein by a single gluconeogenic dispensable amino acid on hepatic glucose metabolism in rainbow trout (Oncorhynchus mykiss). Comparative Biochemistry and Physiology Part A 134: 337-347.

Krogdahl, Å., G. I. Hemre, and T. P. Mommsen. 2005. Carbohydrates in fish nutrition: digestion and absorption in postlarval stages. Aquac. Nutr. 11:103-122.

Kumar, V., W. K. B. Khalil, U. Weiler, and K. Becker. 2013. Influences of incorporating detoxified Jatropha curcas kernel meal in common carp (Cyprinus carpio L.) diet on the expression of growth hormone- and insulin-like growth factor1-encoding genes. J. Anim. Physiol. Anim. Nutr (Berl). 97:97108.

Lall, S. P. 1991. Salmonid nutrition and feed production. In: Proceedings of the special session on salmonid aquaculture. World Aquaculture Society, Los Angeles, CA, USA. 107-123.

Leung, L. Y. and N. Y. S. Woo. 2012. Influence of dietary carbohydrate level on endocrine status and hepatic carbohydrate metabolism in the marine fish Sparus sarba. Fish Physiol. Biochem. 38:543-554.

Médale, F., J. M. Poli, F. Vallée, and D. Blanc. 1999. Utilization of 
a carbohydrate-rich diet by common carp reared at 18 and $25^{\circ} \mathrm{C}$. Cybium 23:139-152.

Metón, I., A. Caseras, F. Fernández, and I. V. Baanante. 2004. Molecular cloning of hepatic glucose-6-phosphate catalytic subunit from gilthead sea bream (Sparus aurata): Response of its mRNA levels and glucokinase expression to refeeding and diet composition. Comp. Biochem. Physiol. B Biochem. Mol. Biol. 138:145-153.

Miao, L. H., B. Liu, X. P. Ge, J. Xie, C. P. Zhou, L. K. Pan, R. L. Chen, and Q. L. Zhou. 2011. Effect of high carbohydrate levels in the dietary on growth performance, immunity and transmission electron microscopy (TEM) on hepatic cell of allogynogenetic crucian carp (Carassius auratus gibelio). J. Fish. China 35:221-230.

Moreira, I. S., H. Peres, A. Couto, P. Enes, and A. Oliva-Teles. 2008. Temperature and dietary carbohydrate level effects on performance and metabolic utilization of diets in European sea bass (Dicentrarchus labrax) juveniles. Aquaculture 274:153160.

Panserat, S., F. Médale, J. Brèque, E. Plagnes-Juan, and S. Kaushik. 2000a. A Lack of significant long-term effect of dietary carbohydrates on hepatic glucose-6-phosphatase expression in rainbow trout (Oncorhynchus mykiss). J. Nutr. Biochem. 11:22-29.

Panserat, S., F. Médale, C. Blin, J. Brèque, C. Vachot, E. PlagnesJuan, E. Gomes, R. Krishnamoorthy, and S. Kaushik. 2000 b. Hepatic glucokinase is induced by dietary carbohydrates in rainbow trout, gilthead seabream, and common carp. Am. J. Physiol. 278: R1164-R1170.

Panserat, S., E. Plagnes-Juan, and S. Kaushik. 2002. Gluconeogenic enzyme gene expression is decreased by dietary carbohydrates in common carp (Cyprinus carpio) and gilthead seabream (Sparus aurata). Biochim. Biophys. Acta 1579:35-42.

Peragón, J., J. B. Barroso, L. García-Salguero, M. Higuera, and J. A. Lupiáñez. 1999. Carbohydrates affect protein-turnover rates, growth, and nucleic acid content in the white muscle of rainbow trout (Oncorhynchus mykiss). Aquaculture 179:425437.

Peres, H. and A. Oliva-Teles. 1999. Influence of temperature on protein utilization in juvenile European seabass (Dicentrarchus labrax). Aquaculture 170:337-348.

Pérez-Sánchez, J. and P. Le Bail. 1999. Growth hormone axis as marker of nutritional status and growth performance in fish. Aquaculture 177:117-128.

Person-Le Ruyet, J., K. Mahe, N. Le Bayon, and H. Le Delliou. 2004. Effects of temperature on growth and metabolism in a Mediterranean population of European sea bass, Dicentrarchus labrax. Aquaculture 237:269-280.
Plummer, P. 1987. Glycogen determination in animal tissues. An Introduction to Practical Biochemistry, 3rd edn. McGraw Hill Book, Maidenhead, UK. 332 p.

Ren, M. C., Q. H. Ai, K. S. Mai, H. M. Ma, and X. J. Wang. 2011. Effect of dietary carbohydrate level on growth performance, body composition, apparent digestibility coefficient and digestive enzyme activities of juvenile cobia, Rachycentron canadum L. Aquac. Res. 42:1467-1475.

Roberts, R. J. 1989. Nutritional pathology of teleosts. In: Fish pathology (Ed. R. J. Roberts). Bailliere Tindall, London, UK. 337-362.

Shikata, T., S. Iwanaga, and S. Shimeno. 1995. Regulation of carbohydrate metabolism in fish 25 . Metabolic response to acclimation temperature in carp. Fish. Sci. 61:512-516.

Tan, Q. S., F. Wang, S. Q. Xie, X. M. Zhu, W. Lei, and J. Z. Shen. 2009. Effect of high dietary starch levels on the growth performance, blood chemistry and body composition of gibel carp (Carassius auratus var. gibelio). Aquac. Res. 40:10111018.

Tranulis, M. A., O. Dregni, B. Christophersen, A. Krogdahl, and B. Borrebaek. 1996. A glucokinase-like enzyme in the liver of Atlantic salmon (Salmo salar). Comp. Biochem. Physiol. Biochem. Mol. Biol. 114B:35-39.

Tymchuk, W. E., B. Beckman, and R. H. Devlin. 2009. Altered expression of growth hormone/insulin-like growth factor I axis hormones in domesticated fish. Endocrinology 150:1809-1816.

Vielma, J., J. Koskela, K. Ruohonen, I. Jokinen, and J. Kettunen. 2003. Optimal diet composition for European whitefish (Coregonus lavaretus): Carbohydrate stress and immune parameter responses. Aquaculture 225:3-16.

Wilson, R. P. 1994. Utilization of dietary carbohydrate by fish. Aquaculture 124:67-80.

Yang, G. H., Q. X. Dai, and L. D. Gu. 1989. Nutrition, feed formulation and high-yield aquaculture techniques of blunt snout bream (Megalobrama amblycephala). Feed Industry 1: 7-10.

Yu, S. K., C. E. Olsen, and J. Marcussen. 1997. Methods for the assay of 1,5-anhydro-D-fructose and $\alpha$-1,4-glucanlyase. Carbohydr. Res. 305:73-82.

Zhou, C. P., B. Liu, J. Xie, X. P. Ge, P. Xu, Q. L. Zhou, L. K. Pan, and R. L. Chen. 2013. Effect of dietary carbohydrate level on growth performance, blood chemistry, hepatic enzyme activity, and growth hormone gene expression in Wuchang bream (Megalobrama amblycephala). The Israeli Journal of Aquaculture - Bamidgeh, IJA_65.2013.882, 8 pages.

Zhou, Z., Z. Ren, H. Zeng, and B. Yao. 2008. Apparent digestibility of various feedstuffs for blunt nose black bream Megalobrama amblycephala Yih. Aquac. Nutr. 14:153-165. 